\title{
DUOX2 variants are a frequent cause of congenital primary hypothyroidism in Thai patients
}

\author{
Kinnaree Sorapipatcharoen ${ }^{1}$, Thipwimol Tim-Aroon ${ }^{1}$, Pat Mahachoklertwattana ${ }^{1}$, Wasun Chantratita ${ }^{2}$, \\ Nareenart lemwimangsa ${ }^{2}$, Insee Sensorn ${ }^{2}$, Bhakbhoom Panthan ${ }^{2}$, Poramate Jiaranai ${ }^{2}$, Saisuda Noojarern ${ }^{1}$, \\ Chutintorn Sriphrapradang ${ }^{4}$ and Preamrudee Poomthavorn ${ }^{1}$

\begin{abstract}
'Department of Pediatrics, Faculty of Medicine Ramathibodi Hospital, Mahidol University, Bangkok, Thailand ${ }^{2}$ Center for Medical Genomics, Faculty of Medicine Ramathibodi Hospital, Mahidol University, Bangkok, Thailand ${ }^{3}$ Research Center, Faculty of Medicine Ramathibodi Hospital, Mahidol University, Bangkok, Thailand

${ }^{4}$ Department of Medicine, Faculty of Medicine Ramathibodi Hospital, Mahidol University, Bangkok, Thailand
\end{abstract} Patcharin Khlairit ${ }^{1}$, Sarunyu Pongratanakul ${ }^{1}$, Chittiwat Suprasongsin ${ }^{3}$, Manassawee Korwutthikulrangsri ${ }^{1}$,

Correspondence should be addressed to P Poomthavorn: preamrudee.poo@mahidol.ac.th

\begin{abstract}
Objective: To identify the genetic etiologies of congenital primary hypothyroidism $(\mathrm{CH})$ in Thai patients.

Design and methods: $\mathrm{CH}$ patients were enrolled. Clinical characteristics including age, signs and symptoms of $\mathrm{CH}$, pedigree, family history, screened thyroid-stimulating hormone results, thyroid function tests, thyroid imaging, clinical course and treatment of $\mathrm{CH}$ were collected. Clinical exome sequencing by next-generation sequencing was performed. In-house gene list which covered 62 potential candidate genes related to $\mathrm{CH}$ and thyroid disorders was developed for targeted sequencing. Sanger sequencing was performed to validate the candidate variants. Thyroid function tests were determined in the heterozygous parents who carried the same DUOX2 or DUOXA2 variants as their offsprings.

Results: There were 118 patients (63 males) included. Mean (SD) age at enrollment was 12.4 (7.9) years. Forty-five of 118 patients (38\%) had disease-causing variants. Of 45 variants, 7 genes were involved (DUOX2, DUOXA2, TG, TPO, SLC5A5, PAX8 and TSHR). $D \cup O X 2$, a gene causing thyroid dyshormonogenesis, was the most common defective gene $(25 / 45,56 \%)$. The most common DUOX2 variant found in this study was c.1588A>T. $T G$ and TPO variants were less common. Fourteen novel variants were found. Thyroid function tests of most parents with heterozygous state of DUOX2 and DUOXA2 variants were normal.

Conclusions: DUOX2 variants were most common among Thai $\mathrm{CH}$ patients, while $T G$ and TPO variants were less common. The c.1588A>T in DUOX2 gene was highly frequent in this population.
\end{abstract}

Key Words
congenital hypothyroidism
next generation
sequencing
DUOX2
thyroid
dyshormonogenesis
thyroid dysgenesis
goiter

Endocrine Connections (2020) 9, 1121-1134

\section{Introduction}

Congenital primary hypothyroidism $(\mathrm{CH})$ is classified into thyroid dysgenesis (TD) and thyroid dyshormonogenesis (TDH) (1). TDH has increasingly been reported while the incidence of TD has remained stable $(2,3)$. Genetic studies have provided more information on the causes of $\mathrm{CH}(2$, $4,5,6$ ). To date, more than 20 disease-causing genes have https://ec.bioscientifica.com https://doi.org/10.1530/EC-20-0411 (c) 2020 The authors Published by Bioscientifica Ltd
This work is licensed under a Creative Commons Attribution-NonCommercial-NoDerivatives 4.0 enternationad bicense.ifica.com at 04/26/2023 02:56:12AM 
been reported to be linked with the pathogenesis of $\mathrm{CH}$ $(1,7,8,9,10)$. TD is defined as abnormal thyroid gland development including ectopic gland, hypoplasia and athyreosis. Genetic etiologies of TD include TSHR, NKX2-1, FOXE1, PAX8, NKX2-5, GLIS3, JAG1, TBX1, NTN1 and CDCA8 variants $(1,11)$. TDH is characterized by thyroid hormone biosynthetic defect. Genetic defects involved in the steps of thyroid hormone synthesis pathway include SLC5A5, SLC26A4, DUOX1, DUOX2, DUOXA1, DUOXA2, TPO, TG, IYD and GNAS genes $(1,11)$.

Identifying genetic causes of $\mathrm{CH}$ has several advantages for patients. Genetic diagnosis provides a risk estimation of thyroidal and extrathyroidal defects in affected patients and families and helps in predicting long-term prognosis in affected individuals (1). Owing to the fact that $\mathrm{CH}$ is a genetically heterogeneous disorder which is caused by variants of various genes, traditional sequencing of candidate genes of $\mathrm{CH}$ demonstrated pathogenic variants in only approximately $10 \%$ of the reported cases (12). Currently, next-generation sequencing (NGS) analysis has been reported to provide an efficient, cost-effective and multigenic screening tool to establish the genetic causes of $\mathrm{CH}$ with the diagnostic yield of $46-59 \%(4,5,6)$.

The incidence of $\mathrm{CH}$ has been increasing worldwide. Previous studies reported varied incidences of $\mathrm{CH}$ depending on race and ethnicity $(13,14,15)$. The $\mathrm{CH}$ incidence was reported at 1:1200-2380 in Asians and 1:3533-11,000 in Caucasians $(13,14)$. TDH was found to be more frequent than TD in patients from China, Iran and United Arab Emirates (2, 16, 17). Genetic analysis revealed that TDH was more frequently associated with DUOX2 variants in patients of Asian origin, including Japan, Korea and China, and with $T G$ and $T P O$ variants in patients from United Kingdom and Finland (2, 5, 6, $18,19)$. This study aimed to investigate the clinical and molecular characteristics of Thai patients with $\mathrm{CH}$.

\section{Materials and methods}

\section{Patients}

All enrolled $\mathrm{CH}$ patients were regularly treated at the Departments of Pediatrics and Medicine, Faculty of Medicine Ramathibodi Hospital, Mahidol University, Bangkok, Thailand. $\mathrm{CH}$ was diagnosed based on the findings of elevated serum thyroid-stimulating hormone (TSH) and low free thyroxine ( $\left.\mathrm{FT}_{4}\right)$ concentrations on either confirmatory test for positive newborn screening (NBS) or thyroid function tests for other signs and symptoms suggesting $\mathrm{CH}$. Patients with transient $\mathrm{CH}$ secondary to maternal conditions, sick euthyroid syndrome and obvious syndromic features were excluded.

Provisional clinical diagnoses of TDH and TD were made in patients who had clinical features, and possibly thyroid scintigraphic or ultrasonographic findings suggestive of the particular diagnoses. Patients with goiter, or normal eutopic or enlarged thyroid gland on the thyroid imaging were classified as having TDH while patients who had absent or small or ectopic thyroid gland on thyroid imaging were considered to have TD. Patients who were not compatible with the two groups were classified as having undetermined cause. Patients with persistently high TSH after levothyroxine $\left(\mathrm{LT}_{4}\right)$ discontinuation after 3 years of age were diagnosed as having permanent $\mathrm{CH}$. 'Transient' $\mathrm{CH}$ was diagnosed based on having normal thyroid function test results following discontinuation of $\mathrm{LT}_{4}$ therapy after 3 years of age and thereafter.

The study was approved by the Ethics Committee on Human Research of the Faculty of Medicine Ramathibodi Hospital, Mahidol University (MURA 2018/844, dated 6 December 2018). The study conformed with the Declaration of Helsinki. Written informed consent was obtained from the patients or their legal guardians.

\section{Clinical data collection}

Clinical characteristics including age, signs and symptoms of $\mathrm{CH}$, pedigree, family history of $\mathrm{CH}$, TSH screening results, thyroid function tests, thyroid imagings, clinical course and treatment of $\mathrm{CH}$ were collected.

\section{DNA extraction and targeted sequencing of candidate genes}

Genomic DNA was extracted from peripheral blood using the QuickGene DNA Whole Blood Kit L (Kurabo, Japan). DNA of the patients was submitted for clinical exome sequencing (CES). CES by NGS was performed by Illumina MiSeq ${ }^{\circledR}$ system (Illumina, USA) using the TruSight One Sequencing Panel ${ }^{\circledR}$. The TruSight One Sequencing Panel ${ }^{\circledR}$ focused on 4811 known disease-causing genes that have been reported to be associated with human diseases. Sequences were aligned with the human reference genome version hg19. Thyroid disorder gene list including genes related to $\mathrm{CH}$, secondary hypothyroidism, thyroid hormone resistance, thyroid hormone metabolism defects and thyroid test abnormalities without thyroid pathology (such as ALB and SERPINA7) was developed in-house. It covered 62 potential candidate genes (Table 1) which are

This work is licensed under a Creative Commons Attribution-NonCommercial-NoDerivatives 4.0 Internationad bicense.ifica.com at 04/26/2023 02:56:12AM 
Table 1 Sixty-two genes that are related to thyroid disorders and covered by the panel used in this study.

\begin{tabular}{|c|c|c|c|c|}
\hline Classification & Genes & $\begin{array}{c}\text { OMIM } \\
\text { number }\end{array}$ & Phenotypes & Inheritance \\
\hline \multirow[t]{8}{*}{ Thyroid dysgenesis } & $N K X 2-1$ & 600635 & $\begin{array}{l}\text { Choreoathetosis, hypothyroidism and neonatal } \\
\text { respiratory distress }\end{array}$ & $A D$ \\
\hline & FOXE1 & 602617 & Bamforth-Lazarus syndrome & $A R$ \\
\hline & PAX8 & 167415 & Thyroid dysgenesis or hypoplasia & $A D$ \\
\hline & $N K X 2-5$ & 600584 & Congenital nongoitrous hypothyroidism & $A D$ \\
\hline & GLIS3 & 610192 & $\begin{array}{l}\text { Neonatal diabetes mellitus with congenital } \\
\text { hypothyroidism }\end{array}$ & AR \\
\hline & $T S H R$ & 603372 & Congenital nongoitrous hypothyroidism & $A R, A D$ \\
\hline & $J A G 1$ & 601920 & Alagille syndrome & $A D$ \\
\hline & $T B X 1$ & 602054 & DiGeorge syndrome & $A D$ \\
\hline \multirow[t]{8}{*}{ Thyroid dyshormonogenesis } & SLC5A5 & 601843 & Thyroid dyshormonogenesis & AR \\
\hline & TPO & 606765 & Thyroid dyshormonogenesis & $A R$ \\
\hline & SLC26A4 & 605646 & Pendred syndrome & $A R$ \\
\hline & $T G$ & 188450 & Thyroid dyshormonogenesis & $A R$ \\
\hline & IYD & 612025 & Thyroid dyshormonogenesis & AR \\
\hline & DUOX2 & 606759 & Thyroid dyshormonogenesis & $A R, A D$ \\
\hline & DUOXA2 & 612772 & Thyroid dyshormonogenesis & $A R, A D$ \\
\hline & GNAS & 139320 & Pseudohypoparathyroidism & $A D$ \\
\hline \multirow[t]{11}{*}{ Central hypothyroidism } & $T S H B$ & 188540 & Congenital nongoitrous hypothyroidism & $A R$ \\
\hline & $T R H R$ & 188545 & Congenital nongoitrous hypothyroidism & AR \\
\hline & $T B L 1 X$ & 300196 & Congenital nongoitrous hypothyroidism & XLR \\
\hline & HESX1 & 601802 & Combined pituitary hormone deficiencies & $A D, A R$ \\
\hline & LHX3 & 600577 & Combined pituitary hormone deficiencies & $\mathrm{AR}$ \\
\hline & LHX4 & 602146 & Combined pituitary hormone deficiencies & $A D$ \\
\hline & SOX3 & 313430 & Panhypopituitarism & XLR \\
\hline & OTX2 & 600037 & Combined pituitary hormone deficiencies & $A D$ \\
\hline & POU1F1 & 173110 & Combined pituitary hormone deficiencies & $A D, A R$ \\
\hline & PROP1 & 601538 & Combined pituitary hormone deficiencies & $\mathrm{AR}$ \\
\hline & IRS4 & 300904 & Congenital nongoitrous hypothyroidism & XLR \\
\hline \multirow{4}{*}{$\begin{array}{l}\text { Thyroid hormone resistance } \\
\text { and abnormal thyroid } \\
\text { hormone metabolism }\end{array}$} & $T H R B$ & 190160 & Thyroid hormone resistance & $A D, A R$ \\
\hline & THRA & 190120 & Congenital nongoitrous hypothyroidism & $A D$ \\
\hline & SLC16A2 & 300095 & Allan-Herndon-Dudley syndrome & XLR \\
\hline & SECISBP2 & 607693 & Abnormal thyroid hormone metabolism & AR \\
\hline \multirow{21}{*}{$\begin{array}{l}\text { Syndromes or transcription } \\
\text { factors which may be } \\
\text { associated with congenital } \\
\text { hypothyroidism }\end{array}$} & SALL1 & 602218 & Townes-Brocks syndrome & $A D$ \\
\hline & UBR1 & 605981 & Johanson-Blizzard syndrome & AR \\
\hline & DYRK1A & 600855 & Mental retardation & $A D$ \\
\hline & $E L N$ & 130160 & Supravalvular aortic stenosis & $A D$ \\
\hline & $K D M 6 A$ & 300128 & Kabuki syndrome & XLD \\
\hline & $K M T 2 D$ & 602113 & Kabuki syndrome & $A D$ \\
\hline & KAT6B & 605880 & $\begin{array}{l}\text { Genitopatellar syndrome and Say-Barber-Biesecker- } \\
\text { Young-Simpson syndrome }\end{array}$ & $A D$ \\
\hline & $A L B$ & 103600 & Dysalbuminemic hyperthyroxinemia & $A D$ \\
\hline & ALMS1 & 606844 & Alstrom syndrome & AR \\
\hline & DIO1 & 147892 & Asymptomatic hyperthyroxinemia & $A D$ \\
\hline & DIO2 & 601413 & Asymptomatic hyperthyroxinemia & ND \\
\hline & FGF8 & 600483 & $\begin{array}{l}\text { Hypogonadotropic hypogonadism with or without } \\
\text { anosmia }\end{array}$ & $A D$ \\
\hline & HHEX & 604420 & Thyroid dysgenesis & ND \\
\hline & $N K X 2-3$ & 606727 & Thyroid dysgenesis & ND \\
\hline & $N K X 2-6$ & 611770 & $\begin{array}{l}\text { Conotruncal heart malformations and persistent } \\
\text { truncus arteriosus }\end{array}$ & AR \\
\hline & PTH1R & 168468 & Pseudohypoparathyroidism & ND \\
\hline & PTRH2 & 608625 & $\begin{array}{l}\text { Infantile-onset multisystem neurologic, endocrine, } \\
\text { and pancreatic disease }\end{array}$ & AR \\
\hline & $R Y R 2$ & 180902 & Hyperemesis gravidarum & ND \\
\hline & SERPINA7 & 314200 & Thyroxine binding globulin deficiency & XLR \\
\hline & SLC30A10 & 611146 & Hypermanganesemia with dystonia & AR \\
\hline & SLC01C1 (OATP1C1) & 613389 & Thyroid hormone transporter deficiency & $A R$ \\
\hline
\end{tabular}

https://ec.bioscientifica.com https://doi.org/10.1530/EC-20-0411 (c) 2020 The authors Published by Bioscientifica Ltd
This work is licensed under a Creative Commons Attribution-NonCommercial-NoDerivatives 4.0

elfternationad ficense ifica . com at 04/26/2023 02:56:12Am 
Table 1 (Continued)

\begin{tabular}{ll}
\hline Classification & Genes \\
\hline & TTR \\
& $M C 2 R$ \\
& $M R A P$ \\
& $P D E 4 D$ \\
& $P R K A R 1 A$ \\
& $T B C 1 D 24$ \\
& $T R A P P C 9$ \\
& $T X N R D 2$ \\
& FOXI1 \\
& $K C N / 10$ \\
&
\end{tabular}

\begin{tabular}{c|c}
\hline $\begin{array}{c}\text { OMIM } \\
\text { number }\end{array}$ \\
\hline 176300 \\
607397 \\
\\
609196 \\
600129 \\
188830 \\
613577 \\
\\
611966 \\
606448 \\
601093 \\
602208 \\
\hline
\end{tabular}

ACTH, adrenocorticotropic hormone; AD, autosomal dominant; AR, autosomal recessive; OMIM, online Mendelian inheritance in men; ND, no data; XLD, $\mathrm{X}$-linked dominant; XLR, X-linked recessive.

known to be related to thyroid disorders according to the previous reports $(7,8,9,10)$. Some genes related to syndromic $\mathrm{CH}$ were included to detect genetic variants in patients who might not have recognizable features. Of the 62 genes, there were 16 genes that are related to TD and TDH.

The variant annotation was performed with VarSeq ${ }^{\circledR}$ Software version 2.1.1 (Golden Helix, USA). Candidate variants were filtered based on in-house developed thyroid disorder gene list and minor allele frequency (MAF) of less than 0.05 across the online databases (e.g. gnomAD, 1000 Genomes, ExAC, dbSNP and ClinVar) and in-house Thai database (455 persons). Using the American College of Medical Genetics and Genomics (ACMG) 2015 variant classification guidelines together with Varsome ${ }^{\circledR}$ software (Saphetor, Switzerland), the clinical interpretation of selected variants was determined $(20,21)$. Computational and prediction data using in silico tools were done as one of the ACMG criteria. Variants that were classified as pathogenic or likely pathogenic were considered to be definite causes of $\mathrm{CH}$ in the patients. Variants that did not meet the criteria of pathogenic, likely pathogenic, benign or likely benign, would be classified as variant of uncertain significance (VUS). Sanger sequencing was performed to validate the candidate variants in all patients and their parents. In index cases who had siblings with $\mathrm{CH}$, their $\mathrm{CH}$ siblings were analyzed for the same variants by Sanger sequencing. Thyroid function tests including $\mathrm{FT}_{4}$, TSH and thyroglobulin ( $\mathrm{Tg}$ ) concentrations were determined in the heterozygous parents who carried the same DUOX2 or DUOXA2 variants as their offsprings. Genotype and phenotype correlation of $\mathrm{CH}$ was analyzed.

\section{Phenotypes}

Dystransthyretinemic hyperthyroxinemia

Glucocorticoid deficiency due to ACTH unresponsiveness

Glucocorticoid deficiency

Acrodysostosis with or wi Acrodysostosis with or without hormone resistance $A D$

Deafness, onychodystrophy, osteodystrophy, mental AR retardation and seizures (DOORS) syndrome Mental retardation

Glucocorticoid deficiency

AR

Enlarged vestibular aqueduct

Enlarged vestibular aqueduct
AR

\section{Inheritance}

AD

AR

AR

$A D$

AR

\section{Statistical analysis}

Data were analyzed using SPSS version 22.0 (IBM Corp). Normally and non-normally distributed data were expressed as mean and s.D., and median and interquartile range (IQR), respectively. Mann-Whitney U test was used for comparison between two groups of non-normally distributed data. A $P$-value of less than 0.05 was considered statistically significant.

\section{Results}

A total of 120 Thai patients with $\mathrm{CH}$ were enrolled. Two patients with syndromic features were excluded. Therefore, 118 patients from 109 families were included in the analysis. Eighteen patients were siblings in 9 families. There was no history of consanguinity. There were 55 females and 63 males. Mean (s.D.) age at enrollment was 12.4 (7.9) years. Of the 118 patients, 41 (35\%), 22 (19\%) and $55(46 \%)$ patients were clinically classified as having TDH, TD and undetermined cause, respectively. Ninetyone patients (77\%) were identified through positive NBS. The remaining 27 patients presented with hypothyroidrelated symptoms (21 patients), ectopic thyroid gland (5 patients) and non-autoimmune thyroid goiter (1 patient). There were 92 and 11 patients with permanent and transient $\mathrm{CH}$, respectively. The remaining 15 patients were less than 3 years of age at the time of enrollment, therefore their permanence awaited to be determined.

CES analysis revealed seven $\mathrm{CH}$-causing genes in 39 out of 109 families (45 out of 118 patients, 38\%). Thirty-six out of 45 patients (80\%) had variants in the

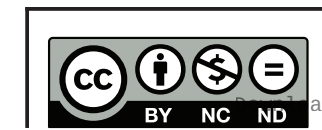

This work is licensed under a Creative Commons Attribution-NonCommercial-NoDerivatives 4.0 International License ifica . com at $04 / 26 / 2023 \quad 02: 56: 12 \mathrm{AM}$ 
genes related to TDH, including DUOX2 $(n=25)$, DUOXA2 $(n=6), T G(n=2), T P O(n=2)$ and SLC5A5 $(n=1)$; and the remaining 9 patients (20\%) had variants in the genes related to TD, including TSHR $(n=5)$ and PAX8 $(n=4)$. There were 14 novel pathogenic variants, including 4 DUOX2 variants, 2 DUOXA2 variants, $2 T G$ variants, 1 SLC5A5 variant, 3 PAX8 variants and 2 TSHR variants (Table 2). There were no pathogenic or likely pathogenic variants in SLC26A4, IYD, GNAS, NKX2-1, FOXE1, NKX2-5, GLIS3, TBX1 and JAG1 genes. VUS were demonstrated in 8 additional patients among the 118 patients (7\%). Among these 8 patients, there were 2 patients who had heterozygous VUS; one had DUOX2 variant (c.2830G $>$ A) and the other had DUOXA2 variant (c.122T>C) which might be responsible for their $\mathrm{CH}$ phenotype. VUS were not included in the reported positive variants.

Clinical characteristics and details of patients with genetic variants are summarized in Table 3. All pathogenic and likely pathogenic variants are shown in Table 2 .

\section{Variants of genes related to TDH}

DUOX2 variants were the most frequent cause of TDH. Twenty-two different DUOX2 variants were identified in 25 patients (23 families). Eighteen out of 25 patients (72\%) carried either compound heterozygous or homozygous variants; and the remaining 7 patients (28\%) had heterozygous variants. The most common pathogenic DUOX2 variant was c. $1588 \mathrm{~A}>\mathrm{T}$, in 10 alleles in 9 patients. While this variant is rare in overall population with MAF of 0.0007 from gnomAD database, it is relatively common in Thai population with MAF of approximately 0.01 in 455 ethnic-matched normal control subjects from our in-house Thai database. Four different DUOXA2 variants were identified in 6 patients ( 5 families), of which three of them had either compound heterozygous or homozygous variants; and the other three had heterozygous variants. The most common DUOXA2 variant was c. $738 \mathrm{C}>\mathrm{G}$, in 5 alleles in 4 patients. Five patients with $D U O X 2$ variants and 2 patients with DUOXA2 variants had transient $\mathrm{CH}$ and 16 patients with DUOX2 variants and 3 patients with DUOXA2 variants had permanent $\mathrm{CH}$. The remaining 4 patients with DUOX 2 variants and 1 patient with DUOXA2 variant were less than 3 years of age at the time of enrollment, so their permanence awaited to be determined. Hypothyroidism in 27 out of 31 patients (87\%) with DUOX2 and DUOXA2 variants was detected by NBS while 3 patients had negative NBS results and prolonged jaundice was the presentation of hypothyroidism. The remaining 1 patient who had Published by Bioscientifica Ltd
DUOXA2 variant presented with enlargement of an ectopic thyroid gland at 5 years of age.

SLC5A5 variant was identified in 1 patient. At 12 years of age following $\mathrm{LT}_{4}$ therapy discontinuation, his thyroid scintigraphy showed no radiotracer uptake but ultrasonography showed normal thyroid gland. TPO variants were detected in 2 patients from the same family. The older brother presented with short stature and diffuse goiter at 8.6 years of age and his sister presented with short stature and multinodular goiter at 6.7 years of age. Additionally, $T G$ variants were found in 2 patients.

\section{Variants of genes related to TD}

The majority of variants of the genes related to TD were found in TSHR gene. Four TSHR variants in 5 patients were detected. Of these 5 patients, 4 had either homozygous or compound heterozygous variants and one patient with subclinical hypothyroidism had heterozygous variant. Four patients with PAX8 variants had varied thyroid phenotypes, including athyreosis, hypoplasia and gland in situ, but absent uptake on thyroid scintigraphy. Two patients presented with short stature during childhood and adolescence.

\section{Genotype-phenotype analysis of patients with DUOX2 variants}

Among 18 patients with biallelic DUOX2 variants, 11 (61\%) had permanent $\mathrm{CH}, 3$ (17\%) had transient $\mathrm{CH}$ and the remaining $4(22 \%)$ were under 3 years of age, whose permanence awaited to be determined. Out of 7 patients with monoallelic DUOX2 variants, 5 had permanent $\mathrm{CH}$ and 2 had transient $\mathrm{CH}$. Median (IQR) serum TSH and $\mathrm{FT}_{4}$ concentrations at diagnosis of patients with monoallelic and biallelic variants were not statistically different [TSH: $50.0(17.7,100.0)$ and $50.0(39.5,100.0)$ $\mathrm{mU} / \mathrm{L}, p=0.604 ; \mathrm{FT}_{4}: 0.9(0.4,1.3)$ and $0.6(0.4,0.9) \mathrm{ng} / \mathrm{dL}$, $p=0.482$, respectively]. There was no evidence of genotypephenotype correlation.

\section{Segregation analysis of patients with DUOX2 and DUOXA2 variants}

Serum $\mathrm{FT}_{4}$, TSH and $\mathrm{Tg}$ concentrations were determined in 29 heterozygous parents from 17 families of patients who carried variants of the DUOX2 and DUOXA2 genes (Fig. 1 and Table 4). Regarding patients with compound heterozygous and homozygous variants in the DUOX2 and
This work is licensed under a Creative Commons Attribution-NonCommercial-NoDerivatives 4.0 International License ifica com at $04 / 26 / 2023 \quad 02: 56: 12 A M$ 


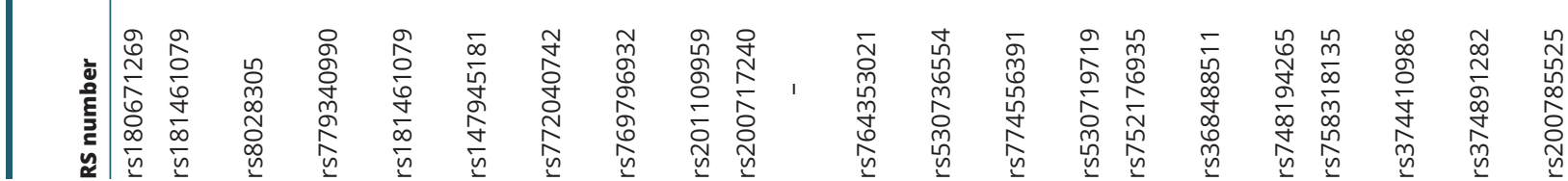

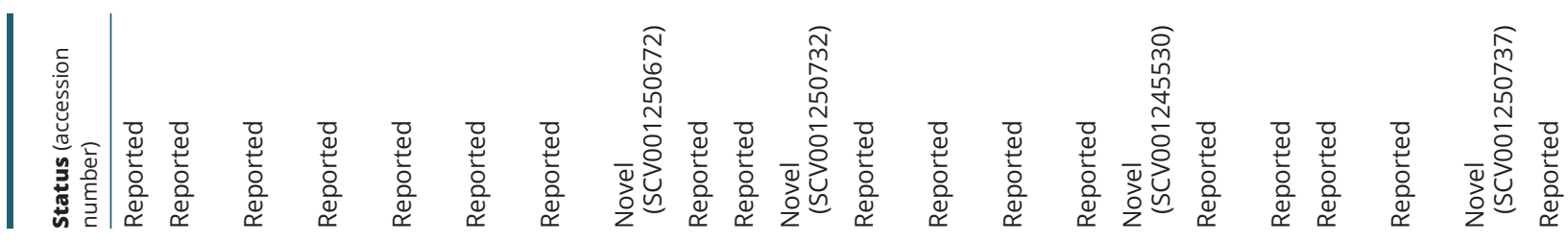

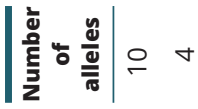

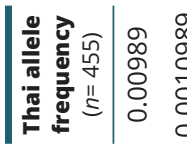

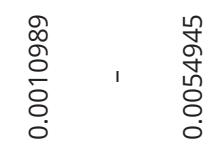

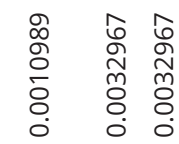

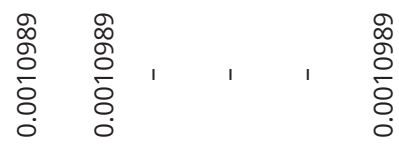
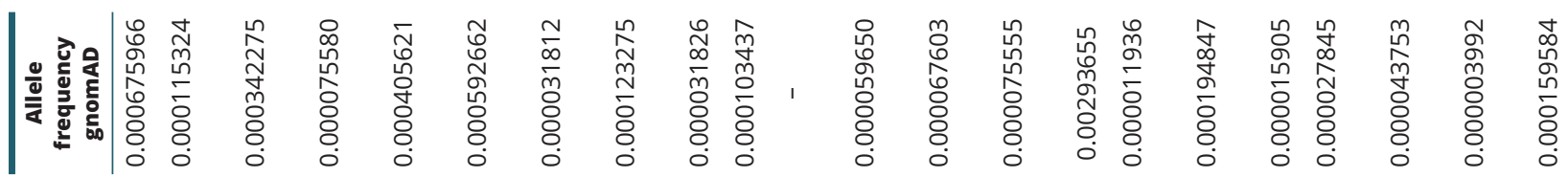

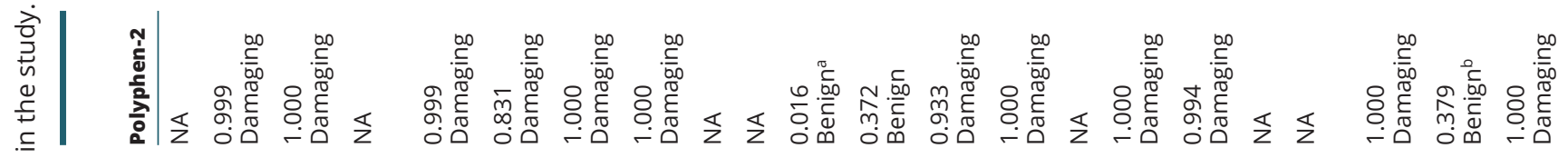

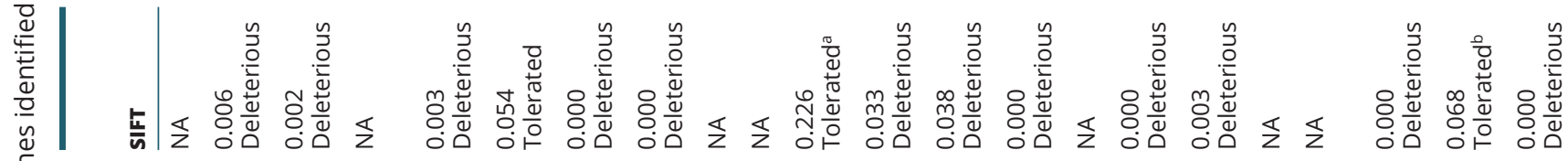

部|

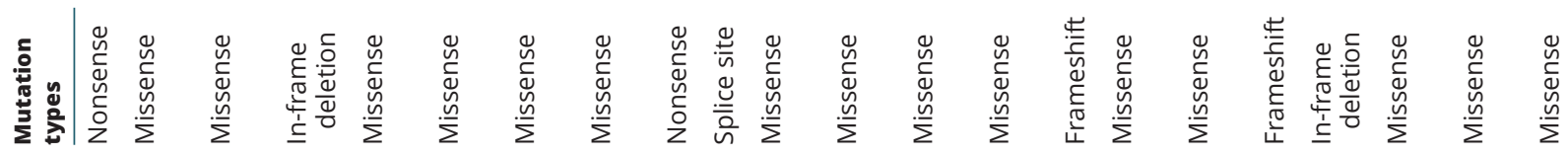
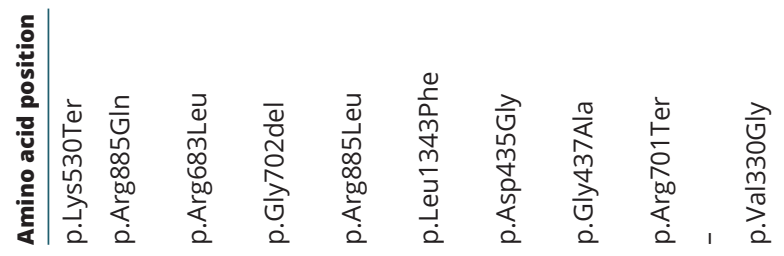

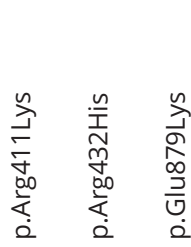

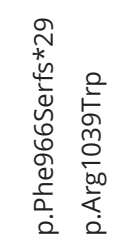

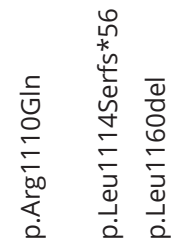
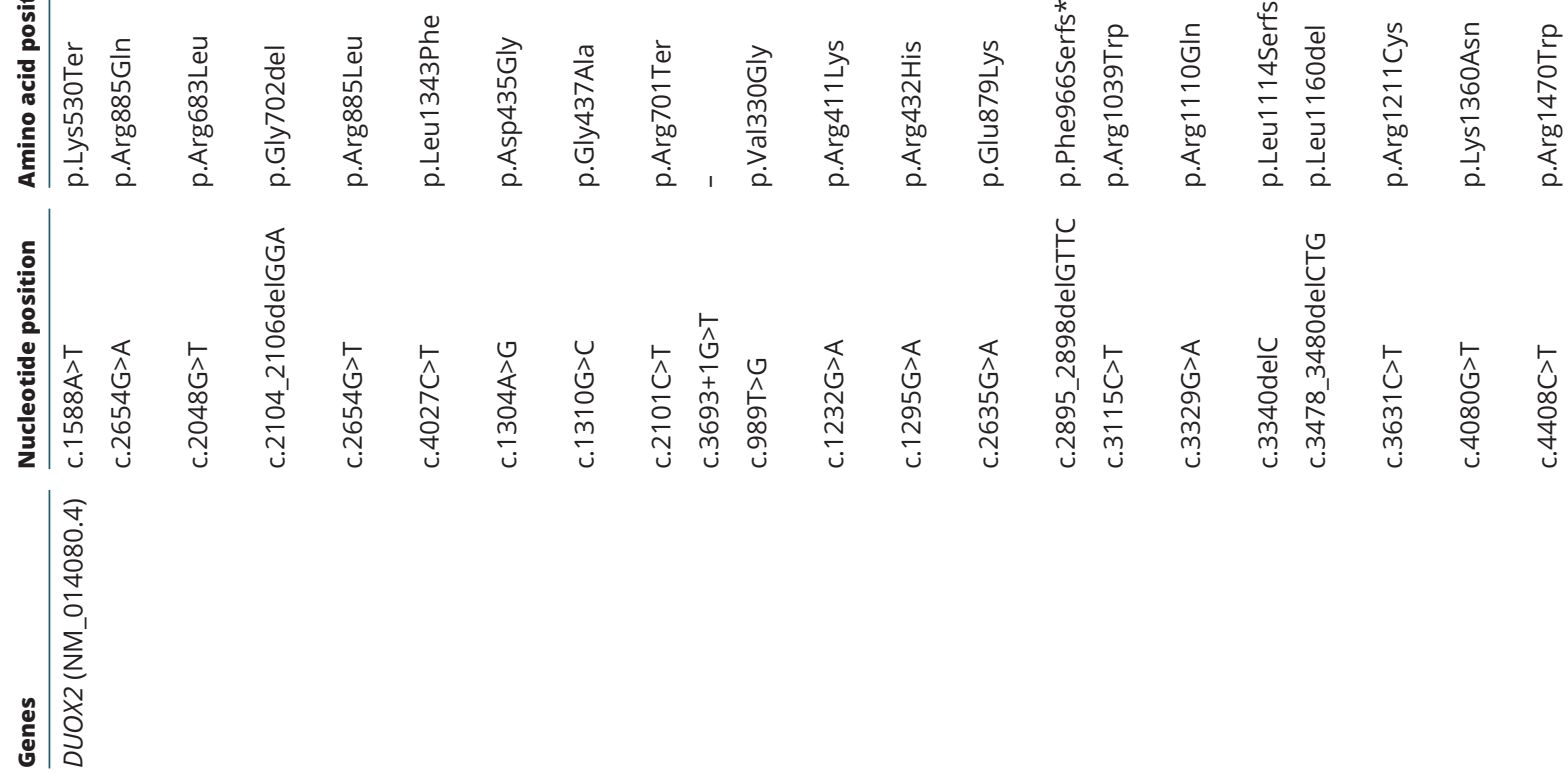

(c) 2020 The authors Published by Bioscientifica Ltd 


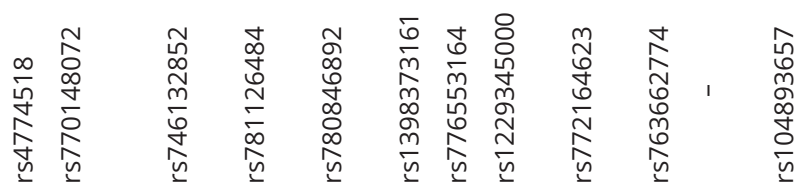

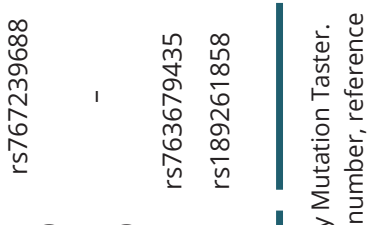

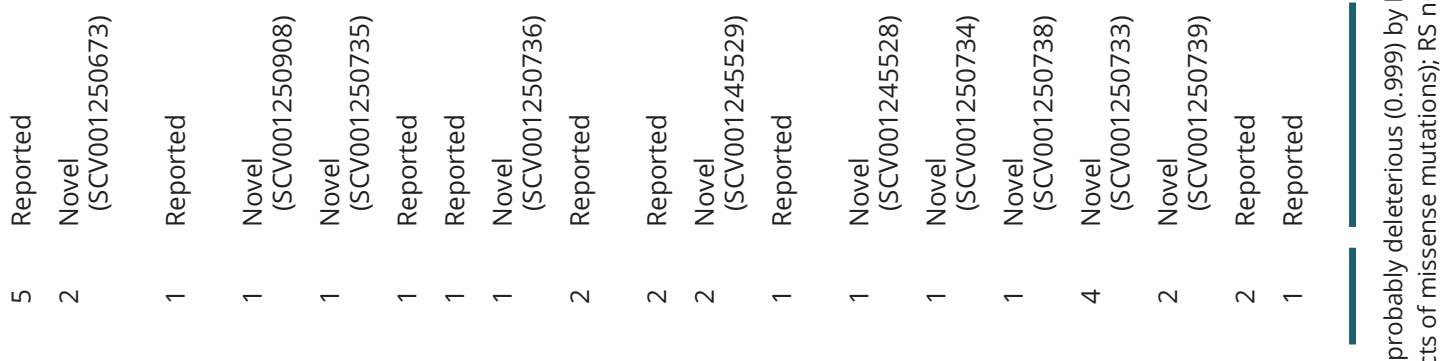

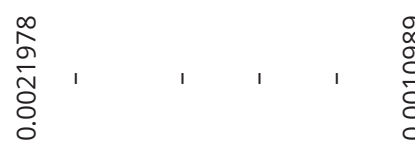<smiles>[CH]1CCCC1</smiles>

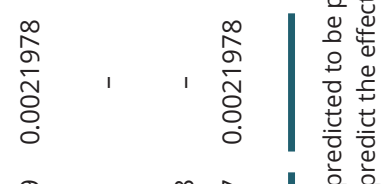

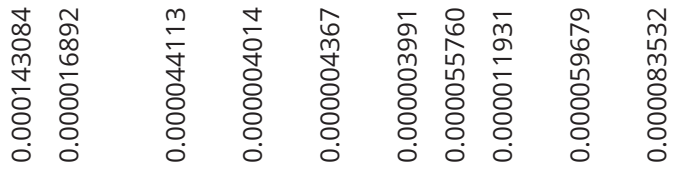

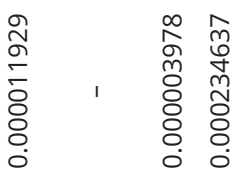

후일

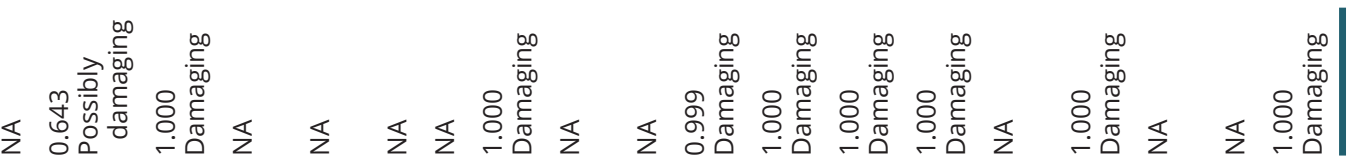

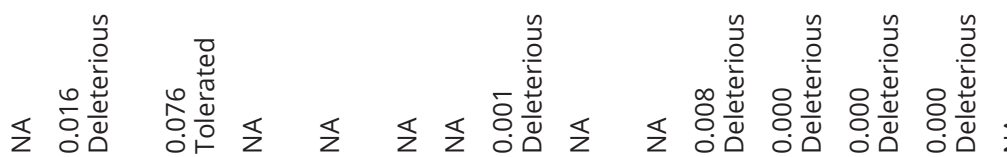

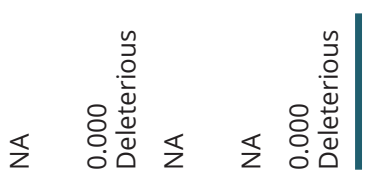
究

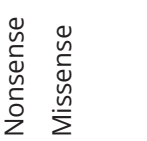
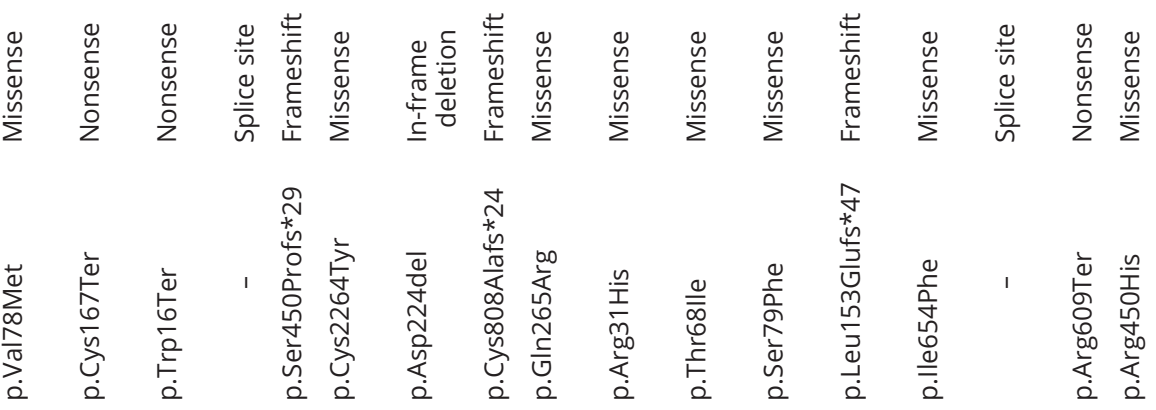

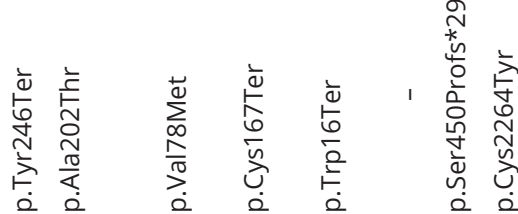
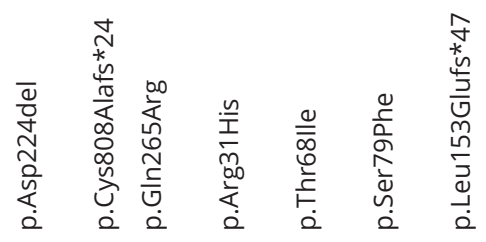

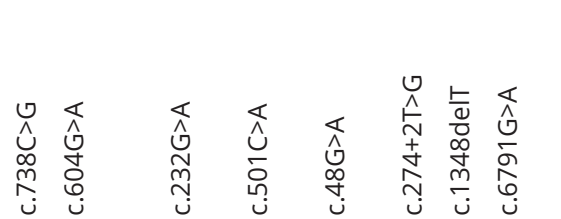
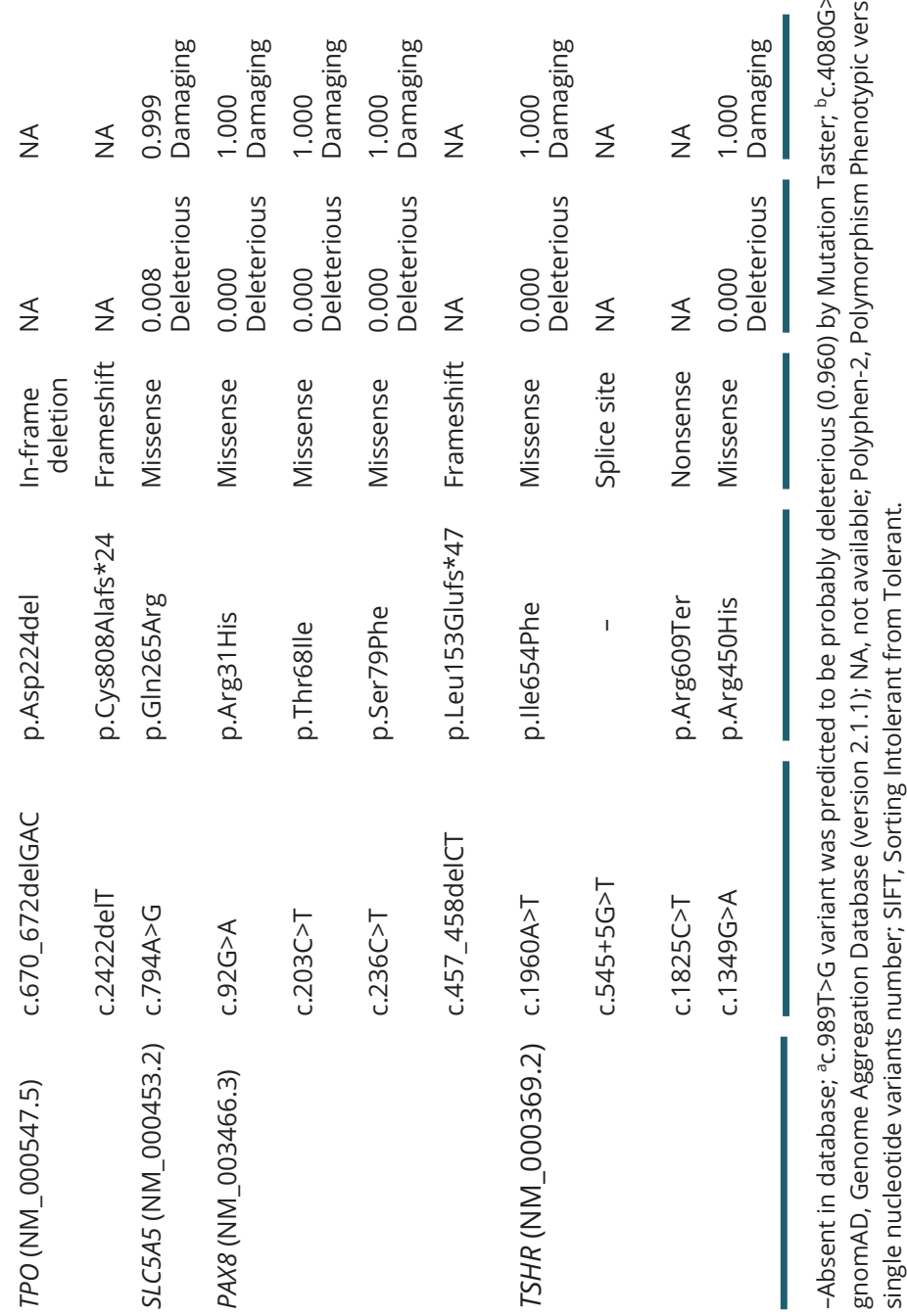

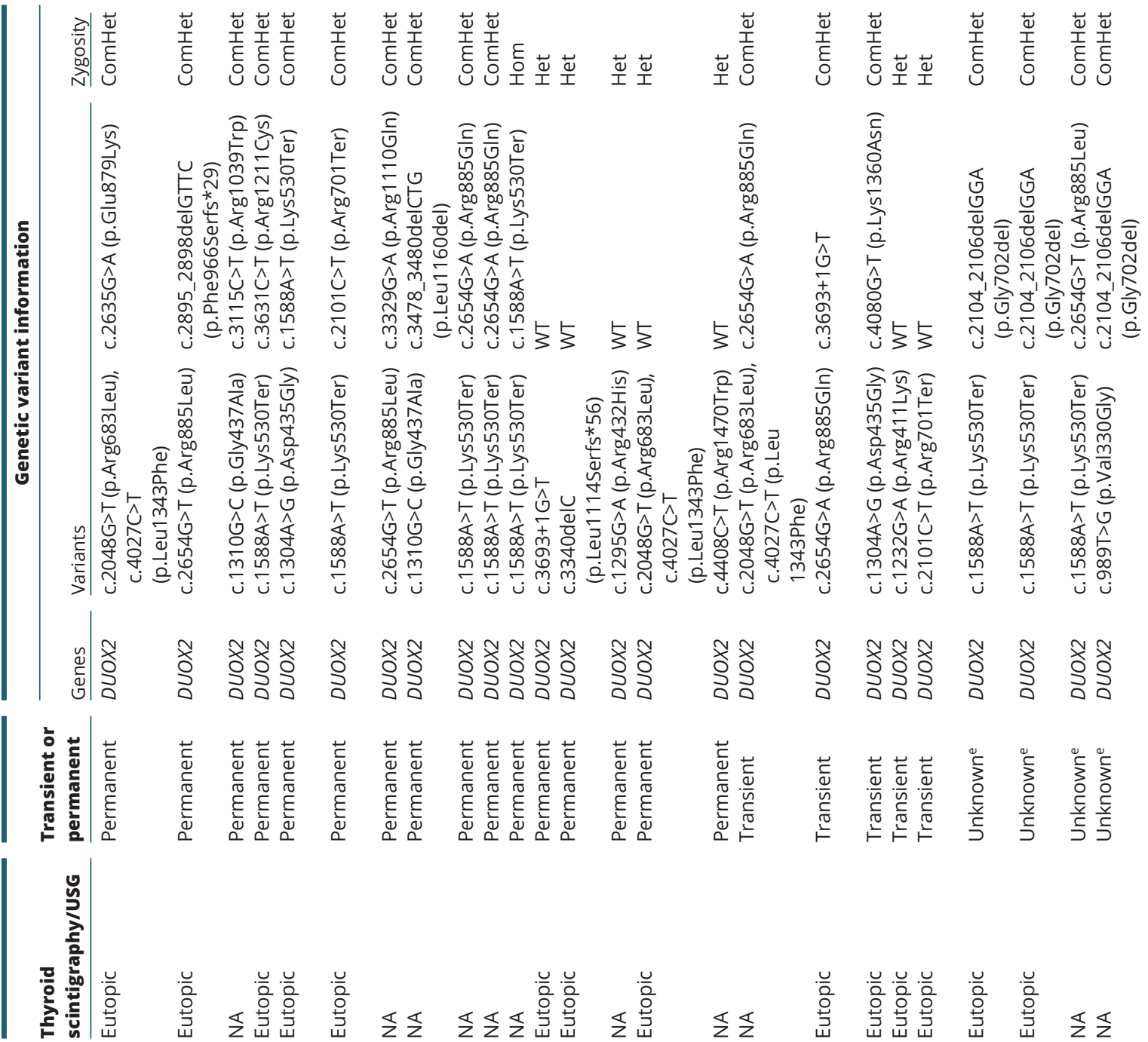

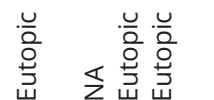

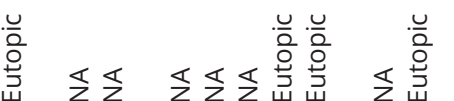

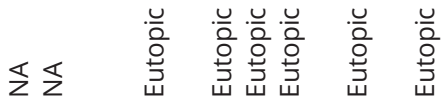

$\sum \frac{\pi}{2}$

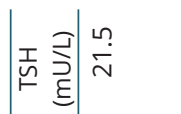

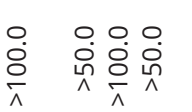

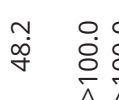

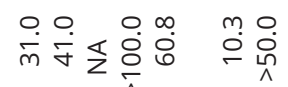

숭용

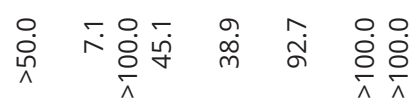

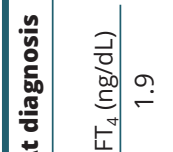

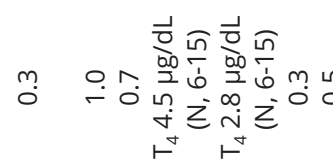

ํ. ㄴํำ芒

ํํㅇ

$\stackrel{\sim}{\sim} \stackrel{+}{0}$

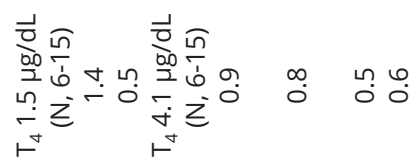

$<$

离

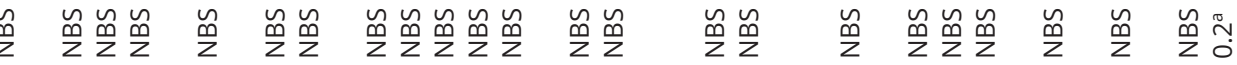

紊|

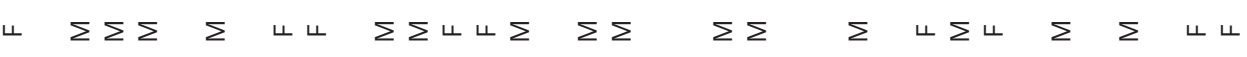

莺

童|

.

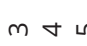

$6 \wedge \infty \quad a \quad=$

$\stackrel{m}{\square}$

$\stackrel{n}{2} \div$

$\stackrel{\infty}{\sim} \stackrel{\sim}{\sim} \bar{N}$

$\stackrel{\sim}{\sim}$ 


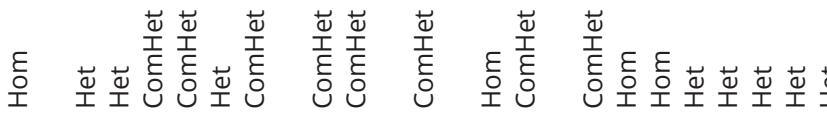

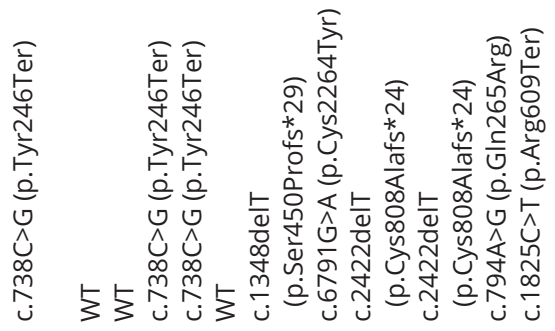

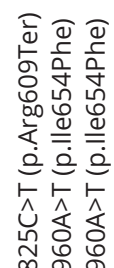

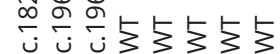
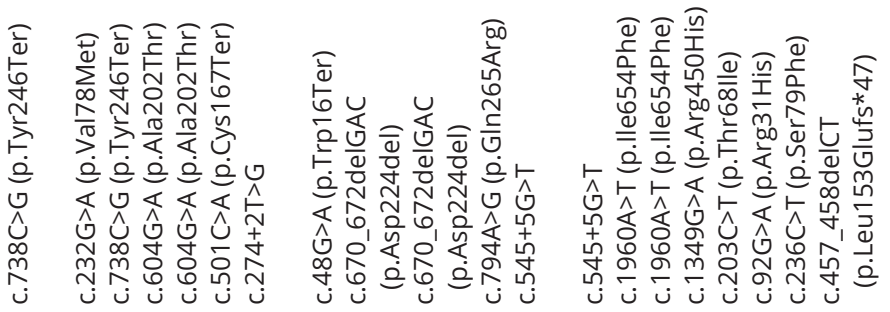

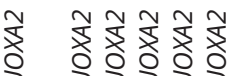

\ั

andan

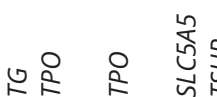

䒿密

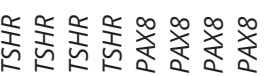

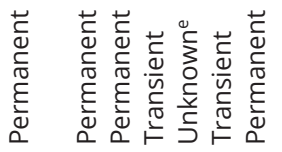

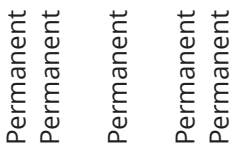

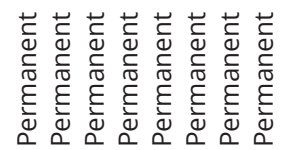

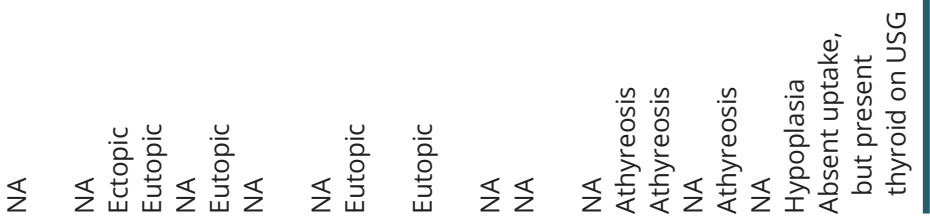

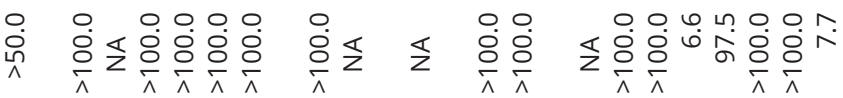

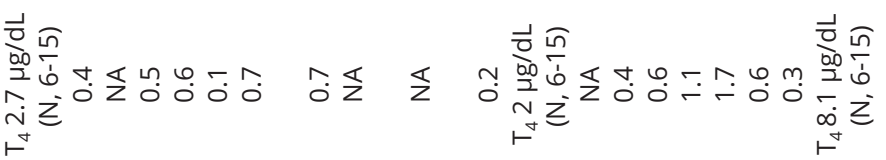

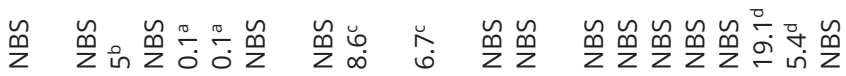

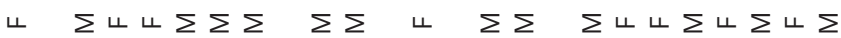

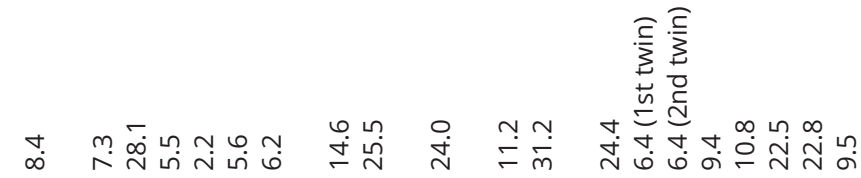

$\stackrel{\sim}{\sim} \stackrel{\sim}{\sim} \quad \stackrel{\infty}{N} \quad$ m $\bar{m}$

$\tilde{m} \tilde{m}$

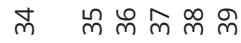


DUOXA2 genes from 12 families which were inherited as an autosomal recessive manner, 22 heterozygous parents had normal $\mathrm{FT}_{4}$, TSH and Tg concentrations, while 2 parents (Families 6 and 16) had mildly elevated $\mathrm{Tg}$ concentrations, but normal $\mathrm{FT}_{4}$ and $\mathrm{TSH}$ (Fig. 1 and Table 4).

Some heterozygous variants of the DUOX2 and DUOXA2 genes have been described as an autosomal dominant inheritance. Four out of five parents who were tested and carried the same heterozygous variants as their offsprings had normal $\mathrm{FT}_{4}$, TSH and Tg concentrations. Only the mother of a patient with DUOX2 defect who carried two variants in the same allele (c.2048G>T and c.4027C $>$ T) had subclinical hypothyroidism which was subsequently found to be related to autoimmune thyroiditis (Fig. 1, family 14 and Table 4).

\section{Discussion}

This study demonstrated that the frequency of genetic defects in the genes causing TDH was more common than that of the genes causing TD (36/118 (30\%) vs 9/118 $(8 \%))$ which was in agreement with the previous studies
$(4,5,22,23,24)$. The most frequently affected gene in this study was DUOX2 (25 out of $45,56 \%$ ). This finding is consistent with the frequency reported in other Asian countries (Korea, Japan and China) at 53-74\% (4, 18, 19). In contrast, $T G$ and TPO variants were demonstrated in 4 out of 45 patients (9\%) which was much less than that of DUOX2 variants. TG and TPO variants have been reported as the most frequent cause of TDH in Western populations $(5,6)$. The high rate of DUOX2 variants in Asians could be explained by the founder effect which contributed to more frequent occurrence of the particular variants compared with other populations. MAF of normal control Thai database of 11 out of 22 DUOX 2 variants identified in this study was greater than that of the general population from the gnomAD (0.001-0.01 vs 0.00002-0.0007) (Table 2).

DUOX 2 requires DUOX1 and their maturation factors (DUOXA1 and DUOXA2) to maintain normal hydrogen peroxide $\left(\mathrm{H}_{2} \mathrm{O}_{2}\right)$ production $(1,25)$. Twenty-two different DUOX2 variants (Table 2) were identified in this cohort. The c.1588A $>$ T in DUOX2 gene was highly recurrent in 9 out of 25 patients (36\%) with DUOX2 variants in our cohort. The c.1588A $>\mathrm{T}$ variant had populationspecificity and was mainly reported from Asian countries (26, 27, 28). Interestingly, among these 9 patients who
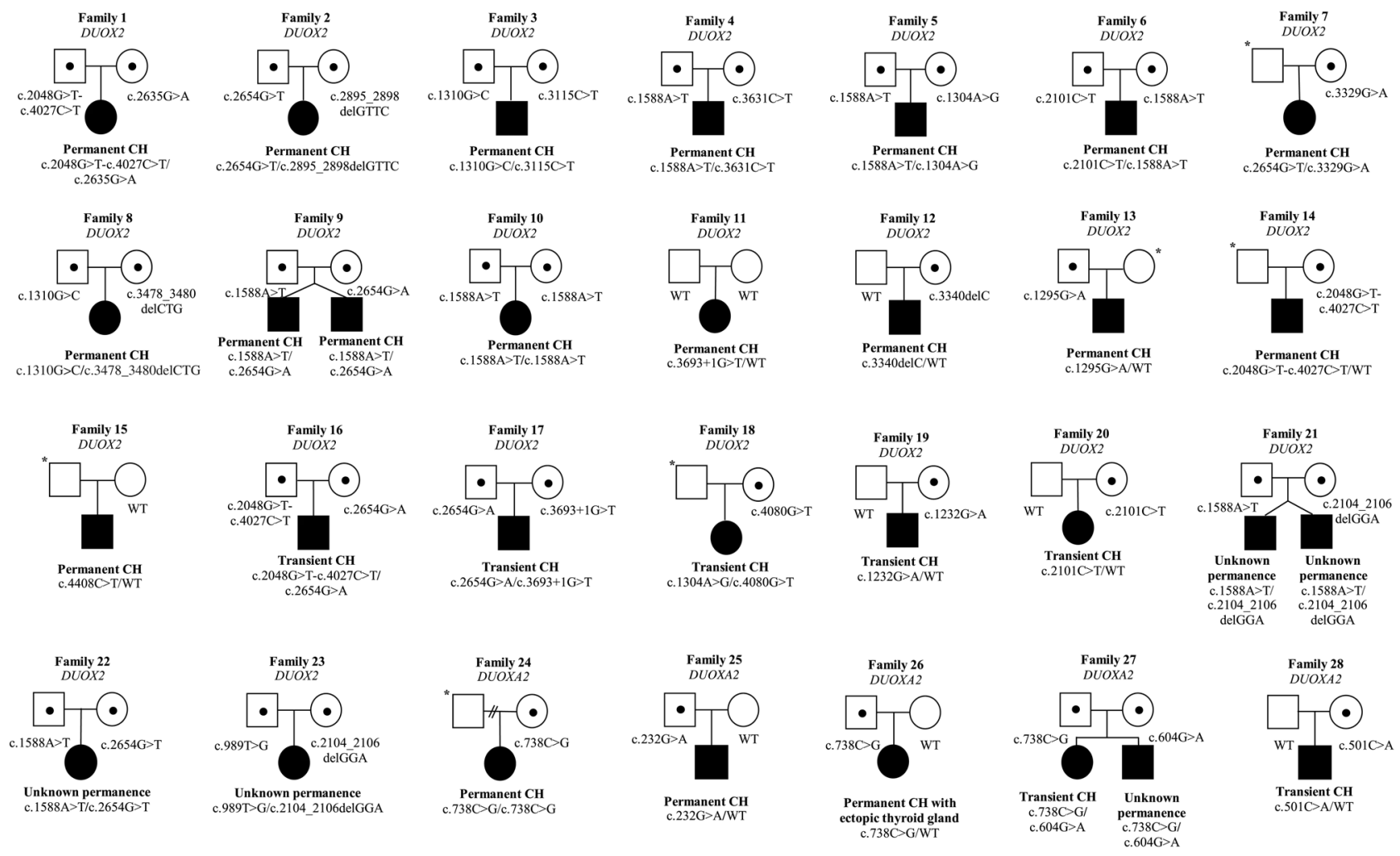

Figure 1

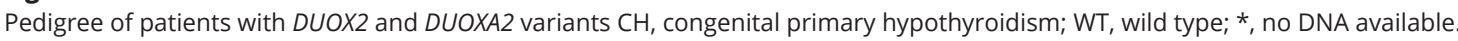

https://ec.bioscientifica.com https://doi.org/10.1530/EC-20-0411 (c) 2020 The authors Published by Bioscientifica Ltd

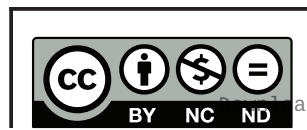

This work is licensed under a Creative Commons Attribution-NonCommercial-NoDerivatives 4.0 elnternationad dicense ifica . com at 04/26/2023 02:56:12AM 
Table 4 Thyroid function tests of the parents of the patients with DUOX2 and DUOXA2 variants.

\begin{tabular}{|c|c|}
\hline Family & Member \\
\hline 1 & $\begin{array}{l}\text { Father } \\
\text { Mother }\end{array}$ \\
\hline 2 & $\begin{array}{l}\text { Father } \\
\text { Mother }\end{array}$ \\
\hline 3 & $\begin{array}{l}\text { Father } \\
\text { Mother }\end{array}$ \\
\hline 4 & $\begin{array}{l}\text { Father } \\
\text { Mother }\end{array}$ \\
\hline 5 & $\begin{array}{l}\text { Father } \\
\text { Mother }\end{array}$ \\
\hline 6 & $\begin{array}{l}\text { Father } \\
\text { Mother }\end{array}$ \\
\hline 7 & $\begin{array}{l}\text { Father } \\
\text { Mother }\end{array}$ \\
\hline 8 & $\begin{array}{l}\text { Father } \\
\text { Mother }\end{array}$ \\
\hline 9 & $\begin{array}{l}\text { Father } \\
\text { Mother }\end{array}$ \\
\hline 10 & $\begin{array}{l}\text { Father } \\
\text { Mother }\end{array}$ \\
\hline 11 & $\begin{array}{l}\text { Father } \\
\text { Mother }\end{array}$ \\
\hline 12 & $\begin{array}{l}\text { Father } \\
\text { Mother }\end{array}$ \\
\hline 13 & $\begin{array}{l}\text { Father } \\
\text { Mother }\end{array}$ \\
\hline 14 & $\begin{array}{l}\text { Father } \\
\text { Mother }\end{array}$ \\
\hline 15 & $\begin{array}{l}\text { Father } \\
\text { Mother }\end{array}$ \\
\hline 16 & $\begin{array}{l}\text { Father } \\
\text { Mother }\end{array}$ \\
\hline 17 & $\begin{array}{l}\text { Father } \\
\text { Mother }\end{array}$ \\
\hline 18 & $\begin{array}{l}\text { Father } \\
\text { Mother }\end{array}$ \\
\hline 19 & $\begin{array}{l}\text { Father } \\
\text { Mother }\end{array}$ \\
\hline 20 & $\begin{array}{l}\text { Father } \\
\text { Mother }\end{array}$ \\
\hline 21 & $\begin{array}{l}\text { Father } \\
\text { Mother }\end{array}$ \\
\hline 22 & $\begin{array}{l}\text { Father } \\
\text { Mother }\end{array}$ \\
\hline 23 & $\begin{array}{l}\text { Father } \\
\text { Mother }\end{array}$ \\
\hline 24 & $\begin{array}{l}\text { Father } \\
\text { Mother }\end{array}$ \\
\hline 25 & $\begin{array}{l}\text { Father } \\
\text { Mother }\end{array}$ \\
\hline 26 & $\begin{array}{l}\text { Father } \\
\text { Mother }\end{array}$ \\
\hline 27 & $\begin{array}{l}\text { Father } \\
\text { Mother }\end{array}$ \\
\hline 28 & $\begin{array}{l}\text { Father } \\
\text { Mother }\end{array}$ \\
\hline
\end{tabular}

\begin{tabular}{c}
\hline $\mathbf{F T}_{\mathbf{4}}(\mathrm{ng} / \mathrm{dL})$ \\
\hline 1.0 \\
1.0 \\
$\mathrm{ND}$ \\
$\mathrm{ND}$
\end{tabular}

$\frac{\mathbf{T S H}(\mathrm{mU} / \mathrm{L})}{0.8}$

\begin{tabular}{c}
$\mathbf{T g}(\mathrm{ng} / \mathrm{mL})$ \\
\hline 5.6 \\
18.3
\end{tabular}

2.0

ND

8.3

ND

0.8

ND

ND

Mother $\quad 0.8$

0.9

3.7

Mother $\quad 1.0$

3.7

16.7

0.9

1.6

14.6

Mother $\quad 1.1$

1.9

1.3

14.3

1.1
0.9

1.0

4.0

1.7

81.2

ND

ND

0.9

0.9

ND

ND

ND

ND

ND

ND

ND

ND

1.0

ND

ND

0.8

ND

ND

1.2

1.0

0.9

0.9

ND

ND

ND

1.0

ND

ND

1.1

0.9

1.0

0.8

1.0

1.0

ND

ND

ND

ND

1.3

ND

0.9

9.3

$\begin{array}{ll}\text { ND } & \text { ND } \\ \text { ND } & \text { ND }\end{array}$

$\begin{array}{ll}0.5 & 5.8\end{array}$

$1.0 \quad 5.1$

ND ND

ND ND

ND ND

ND ND

ND ND

ND ND

ND ND

ND ND

$0.5 \quad 11.7$

ND ND

ND ND

$10.5 \quad 3.7$

ND ND

ND ND

$1.3 \quad 8.5$

$\begin{array}{ll}1.1 & 83.1\end{array}$

2.7

$0.6 \quad 3.6$

ND ND

ND ND

ND ND

$0.6 \quad 7.3$

ND ND

ND ND

$1.5 \quad 13.9$

$\begin{array}{ll}2.0 & 7.2\end{array}$

$1.4 \quad 4.2$

$\begin{array}{ll}1.4 & 12.0\end{array}$

$\begin{array}{ll}0.9 & 12.1\end{array}$

$1.3 \quad 38.0$

ND

ND ND

ND ND

ND ND

$0.7 \quad 34.7$

ND ND

$0.7-7.3$

$\begin{array}{lll}0.9 & 2.8 & 26.8 \\ \text { ND } & \text { ND } & \text { ND }\end{array}$

$\mathrm{T}_{4} 7 \mu \mathrm{g} / \mathrm{dL}(\mathrm{N}, 4-13)$

1.7

ND

$\mathrm{FT}_{4}$, free thyroxine; $\mathrm{T}_{4}$, thyroxine; $\mathrm{TSH}$, thyroid-stimulating hormone; $\mathrm{Tg}$, thyroglobulin; ND, not done.

Adult normal ranges for $\mathrm{FT}_{4}$ 0-7-1.4 ng/dL, TSH 0.6-4.5 mU/L, Tg 3.5-77.0 ng/mL. To convert $\mathrm{FT}_{4}$ in ng/dL to pmol/L, multiply by $12.9 ; \mathrm{TSH}$ in $\mathrm{mU} / \mathrm{L}$ to $\mu \mathrm{lU} / \mathrm{mL}$ multiply by 1.0 and $\mathrm{Tg}$ in $\mathrm{ng} / \mathrm{mL}$ to $\mu \mathrm{g} / \mathrm{L}$ multiply by 1.0 .

https://ec.bioscientifica.com

https://doi.org/10.1530/EC-20-0411 (c) 2020 The authors Published by Bioscientifica Ltd

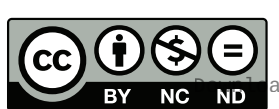

This work is licensed under a Creative Commons Attribution-NonCommercial-NoDerivatives 4.0

delnternationab dicense ifica.com at 04/26/2023 02:56:12AM 
carried c.1588A $>\mathrm{T}$ in both compound heterozygous and homozygous patterns, 6 of them had permanent $\mathrm{CH}$ and the remaining 3 were less than 3 years of age whose permanence awaited to be determined. Therefore, most patients with c. $1588 \mathrm{~A}>\mathrm{T}$ variant in this study had permanent $\mathrm{CH}$. However, previous studies demonstrated that the clinical phenotype of patients carrying c.1588A $>\mathrm{T}$ in each different genotype (biallelic and monoallelic variants) had both transient and permanent $\mathrm{CH}(27,29)$. The difference in the phenotype of patients who had the same variants among studies could be explained by the difference in thyroid hormone requirement with various ages, iodine status, variable variants in the other allele and variable $\mathrm{H}_{2} \mathrm{O}_{2}$ supply by DUOX1/DUOXA1 system (27). This study found double variants in the same allele (c.2048G>T and c.4027C>T) in 3 patients (Table 3, families 1, 14 and 16). Although, there was a study which demonstrated increased severity in patients who had greater number of variants (29), this study demonstrated that 2 patients with compound heterozygous variants 3 variants) had both transient and permanent $\mathrm{CH}$, but the patient who had heterozygous variant ( 2 variants) experienced permanent $\mathrm{CH}$. These heterozygous variants have never been reported as a cause of $\mathrm{CH}$, so functional studies of these variants are required. Additionally, c.2895_2898delGTTC variant which was commonly reported in Western population (30), was found in only one patient in this study. Therefore, the variant frequency seemed to be ethnic specific.

Four different variants in DUOXA2 gene were identified in this study. The nonsense variant c.738C $>\mathrm{G}$ was the most frequent DUOXA2 variant. Its functional studies have already been performed $(31,32)$. In normal control Thai database, this variant had low MAF of 0.002. Interestingly, this variant in DUOXA2 gene which is usually related to $\mathrm{TDH}$, was found in a heterozygous pattern in the patient who had an ectopic thyroid gland (Table 3, family 26). A previous study reported an association of ectopic thyroid gland with DUOX2 variants (33). We postulate that DUOXA2 variants might also be related to thyroid gland development. However, the functional impact of the heterozygous c.738C $>\mathrm{G}$ variant in DUOXA2 gene was not assessed, and the finding could not exclude DUOX2 or other gene deletions.

Both parents of the patient with homozygous variants of SLC5A5 had a heterozygous state of the variant confirmed by Sanger sequencing. This variant was not identified in our in-house Thai database (455 persons). The parents absolutely denied a history of consanguinity. The homozygous state in the patient could be caused by unrecognized consanguineous history of the family because the parents' hometown was in the northeastern region of Thailand.

Two patients with compound heterozygous $T G$ variants were identified in this study. The c.274+2T>G variant found in 1 patient was a common variant reported in Chinese patients (34). Although TG variants have been reported as the most prevalent cause of TDH in Europeans, they were infrequent in our cohort.

In this study, the compound heterozygous, in-frame deletion (c.670_672delGAC) and frameshift mutations (c.2422delT) in TPO gene were identified in two siblings. Both variants have previously been reported $(35,36)$. Both patients developed goiter during childhood as a $\mathrm{CH}$ presentation which was in accordance with that reported in a Japanese patient who carried the same c.670_672delGAC variant and developed large goiter at 8 years of age (37). Retaining about $50 \%$ of residual peroxidase activity might explain the mild phenotype (35, 37). The development of multinodular goiter was possibly caused by delay in diagnosis and treatment $(37,38)$.

TSHR variants cause variable $\mathrm{CH}$ phenotypes. Hypothyroidism in our patients with either compound heterozygous or homozygous TSHR variants was more severe than those carrying heterozygous variant which was similar to previous reports $(39,40,41)$.

$P A X 8$ variants were inherited via autosomal dominant pattern with variable expressivity (42). Interestingly, our patient with novel c.457_458delCT variant had an absent thyroidal uptake on thyroid scintigraphy, but normal appearance of thyroid gland on ultrasonography which is a characteristic finding of iodide transport defect. Therefore, PAX8 variants might affect sodium iodide symporter expression (43).

This study did not find the variants in the genes related to syndromic defects such as NKX2-1, FOXE1, JAG1 and $T B X 1$ because the patients with obvious syndromic features and typical phenotypes were excluded from the CES analysis.

The strengths of this study include being the first relatively large study of genetic diagnosis of $\mathrm{CH}$ in Thai patients, having comprehensive clinical courses to be analyzed with genetic diagnosis and having thyroid function tests of heterozygous parents of the patients with DUOX 2 and DUOXA2 variants. However, there were some limitations. First, DUOX1 and DUOXA1 genes which are required for fullfunction of DUOX2 and DUOXA2 genes were not included in TruSight One Sequencing Panel ${ }^{\circledR}$. Second, patients with heterozygous variants of DUOX2 and DUOXA2 genes might carry undetected variants in the other allele, because NGS cannot detect a large gene deletion or variants in non-coding https://ec.bioscientifica.com https://doi.org/10.1530/EC-20-0411 (c) 2020 The authors Published by Bioscientifica Ltd
This work is licensed under a Creative Commons Attribution-NonCommercial-NoDerivatives 4.0 enternationab dicense.ifica . com at $04 / 26 / 2023$ 02:56:12AM 
regions. Third, some recently identified genetic defects causing $\mathrm{CH}$ which were not included in the panel used in this study such as SLC26A7 could have been missed. In conclusion, DUOX2 variants were the most common cause of $\mathrm{CH}$ among Thai patients, while $T G$ and TPO variants were less common. The c. $1588 \mathrm{~A}>\mathrm{T}$ in DUOX2 gene was a common variant in this population.

\section{Declaration of interest}

The authors declare that there is no conflict of interest that could be perceived as prejudicing the impartiality of the research reported.

\section{Funding}

This work was supported by a research grant from the Faculty of Medicine Ramathibodi Hospital, Mahidol University, Bangkok, Thailand (CF62002, 2019). T T is a recipient of the Research Career Development Award from the Faculty of Medicine Ramathibodi Hospital, Mahidol University, Bangkok, Thailand.

\section{Author contribution statement}

K S, T T, P M and P P designed the work, collected, analyzed and interpreted data for the work, and drafted the article. W C, N I, I S, B P, P J and S N undertook the laboratory work, analyzed and interpreted data for the work. P K, S P, C S, M K and C S collected the data. All authors read and approved the final article.

\section{Acknowledgement}

We thank Stephen Pinder, a medical education/English specialist for help in proofreading our manuscript.

\section{References}

1 Persani L, Rurale G, de Filippis T, Galazzi E, Muzza M \& Fugazzola L. Genetics and management of congenital hypothyroidism. Best Practice and Research: Clinical Endocrinology and Metabolism 201832 387-396. (https://doi.org/10.1016/j.beem.2018.05.002)

2 Tan M, Huang Y, Jiang X, Li P, Tang C, Jia X, Chen Q, Chen W, Sheng H, Feng Y, et al. The prevalence, clinical, and molecular characteristics of congenital hypothyroidism caused by DUOX2 mutations: a population-based cohort study in Guangzhou. Hormone and Metabolic Research 201648 581-588. (https://doi. org/10.1055/s-0042-112224)

3 Wassner AJ. Congenital hypothyroidism. Clinics in Perinatology 2018 45 1-18. (https://doi.org/10.1016/j.clp.2017.10.004)

4 Sun F, Zhang JX, Yang CY, Gao GQ, Zhu WB, Han B, Zhang LL, Wan YY, Ye XP, Ma YR, et al. The genetic characteristics of congenital hypothyroidism in China by comprehensive screening of 21 candidate genes. European Journal of Endocrinology 2018178 623-633. (https://doi.org/10.1530/EJE-17-1017)

5 Löf C, Patyra K, Kuulasmaa T, Vangipurapu J, Undeutsch H, Jaeschke H, Pajunen T, Kero A, Krude H, Biebermann H, et al. Detection of novel gene variants associated with congenital hypothyroidism in a Finnish patient cohort. Thyroid 201626 1215-1224. (https://doi.org/10.1089/thy.2016.0016)

6 Nicholas AK, Serra EG, Cangul H, Alyaarubi S, Ullah I, Schoenmakers E, Deeb A, Habeb AM, Almaghamsi M, Peters C, et al. Comprehensive screening of eight known causative genes in congenital hypothyroidism with gland-in-situ. Journal of Clinical
Endocrinology and Metabolism 2016101 4521-4531. (https://doi. org/10.1210/jc.2016-1879)

7 Peters C, van Trotsenburg ASP \& Schoenmakers N. Diagnosis of endocrine disease: congenital hypothyroidism: update and perspectives. European Journal of Endocrinology 2018179 R297-R317. (https://doi.org/10.1530/EJE-18-0383)

8 Nicola JP. Clinical relevance of molecular diagnosis in patients with congenital hypothyroidism. Journal of Molecular and Genetic Medicine 201711 1000240. (https://doi.org/10.4172/1747-0862.1000240)

9 Watanabe Y, Bruellman RJ, Ebrhim RS, Abdullah MA, Dumitrescu AM, Refetoff S \& Weiss RE. Congenital hypothyroidism due to oligogenic mutations in two Sudanese families. Thyroid 2019 29 302-304. (https://doi.org/10.1089/thy.2018.0295)

10 Köhler S, Carmody L, Vasilevsky N, Jacobsen JOB, Danis D, Gourdine JP, Gargano M, Harris NL, Matentzoglu N, McMurry JA, et al. Expansion of the human phenotype ontology (HPO) knowledge base and resources. Nucleic Acids Research 201947 D1018-D1027. (https://doi.org/10.1093/nar/gky1105)

11 Cherella CE \& Wassner AJ. Congenital hypothyroidism: insights into pathogenesis and treatment. International Journal of Pediatric Endocrinology 20172017 11. (https://doi.org/10.1186/s13633-017-0051-0)

12 De Felice M \& Di Lauro R. Thyroid development and its disorders: genetics and molecular mechanisms. Endocrine Reviews 200425 722-746. (https://doi.org/10.1210/er.2003-0028)

13 Deng K, He C, Zhu J, Liang J, Li X, Xie X, Yu P, Li N, Li Q \& Wang Y. Incidence of congenital hypothyroidism in China: data from the National Newborn Screening Program, 2013-2015. Journal of Pediatric Endocrinology and Metabolism 201831 601-608. (https://doi. org/10.1515/jpem-2017-0361)

14 Hinton CF, Harris KB, Borgfeld L, Drummond-Borg M, Eaton R, Lorey F, Therrell BL, Wallace J \& Pass KA. Trends in incidence rates of congenital hypothyroidism related to select demographic factors: data from the United States, California, Massachusetts, New York, and Texas. Pediatrics 2010125 (Supplement 2) S37-S47. (https://doi. org/10.1542/peds.2009-1975D)

15 Olivieri A, Fazzini C, Medda E \& Italian Study Group for Congenita Hypothyroidism. Multiple factors influencing the incidence of congenital hypothyroidism detected by neonatal screening. Hormone Research in Paediatrics 201583 86-93. (https://doi. org/10.1159/000369394)

16 Aminzadeh M. Higher prevalence of permanent congenital hypothyroidism in the southwest of Iran mostly caused by dyshormonogenesis: a five-year follow-up study. Archives of Endocrinology and Metabolism 201862 602-608. (https://doi. org/10.20945/2359-3997000000085)

17 Deeb A, Elkadry I, Attia S, Al Suwaidi H, Obaid L \& Schoenmakers NA. Biochemical, radiological, and genetic characterization of congenital hypothyroidism in Abu Dhabi, United Arab Emirates. Journal of Pediatric Endocrinology and Metabolism 2016 29 801-806. (https://doi.org/10.1515/jpem-2015-0275)

18 Narumi S, Muroya K, Asakura Y, Aachi M \& Hasegawa T. Molecular basis of thyroid dyshormonogenesis: genetic screening in population-based Japanese patients. Journal of Clinical Endocrinology and Metabolism 2011 96 E1838-E1842. (https://doi.org/10.1210/jc.2011-1573)

19 Park KJ, Park HK, Kim YJ, Lee KR, Park JH, Park JH, Park HD, Lee SY \& Kim JW. DUOX2 mutations are frequently associated with congenital hypothyroidism in the Korean population. Annals of Laboratory Medicine 201636 145-153. (https://doi.org/10.3343/alm.2016.36.2.145)

20 Richards S, Aziz N, Bale S, Bick D, Das S, Gastier-Foster J, Grody WW, Hegde M, Lyon E, Spector E, et al. Standards and guidelines for the interpretation of sequence variants: a joint consensus recommendation of the American College of Medical Genetics and Genomics and the Association for Molecular Pathology. Genetics in Medicine 201517 405-424. (https://doi.org/10.1038/gim.2015.30)

21 Kopanos C, Tsiolkas V, Kouris A, Chapple CE, Albarca Aguilera M, Meyer R \& Massouras A. VarSome: the human genomic variant

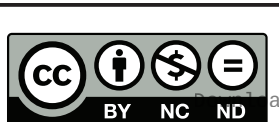

This work is licensed under a Creative Commons Attribution-NonCommercial-NoDerivatives 4.0 International License ifica $_{\text {com }}$ at $04 / 26 / 2023 \quad 02: 56: 12 A M$ 
search engine. Bioinformatics 201935 1978-1980. (https://doi. org/10.1093/bioinformatics/bty897)

22 Yu B, Long W, Yang Y, Wang Y, Jiang L, Cai Z \& Wang H. Newborn screening and molecular profile of congenital hypothyroidism in a Chinese population. Frontiers in Genetics 20189 509. (https://doi. org/10.3389/fgene.2018.00509)

23 Makretskaya N, Bezlepkina O, Kolodkina A, Kiyaev A, Vasilyev EV, Petrov V, Kalinenkova S, Malievsky O, Dedov II \& Tiulpakov A. High frequency of mutations in 'dyshormonogenesis genes' in severe congenital hypothyroidism. PLOS ONE 201813 e0204323. (https:// doi.org/10.1371/journal.pone.0204323)

24 Yamaguchi T, Nakamura A, Nakayama K, Hishimura N, Morikawa S, Ishizu K \& Tajima T. Targeted next-generation sequencing for congenital hypothyroidism with positive neonatal TSH screening. Journal of Clinical Endocrinology and Metabolism 2020105 e2825-e2833. (https://doi.org/10.1210/clinem/dgaa308)

25 Maruo Y, Nagasaki K, Matsui K, Mimura Y, Mori A, Fukami M \& Takeuchi Y. Natural course of congenital hypothyroidism by dual oxidase 2 mutations from the neonatal period through puberty. European Journal of Endocrinology 2016174 453-463. (https://doi. org/10.1530/EJE-15-0959)

26 Long W, Lu G, Zhou W, Yang Y, Zhang B, Zhou H, Jiang L \& Yu B. Targeted next-generation sequencing of thirteen causative genes in Chinese patients with congenital hypothyroidism. Endocrine Journal 201865 1019-1028. (https://doi.org/10.1507/endocrj.EJ18-0156)

27 Maruo Y, Takahashi H, Soeda I, Nishikura N, Matsui K, Ota Y, Mimura Y, Mori A, Sato H \& Takeuchi Y. Transient congenital hypothyroidism caused by biallelic mutations of the dual oxidase 2 gene in Japanese patients detected by a neonatal screening program. Journal of Clinical Endocrinology and Metabolism 200893 4261-4267. (https://doi.org/10.1210/jc.2008-0856)

28 Chow YP, Abdul Murad NA, Mohd Rani Z, Khoo JS, Chong PS, Wu LL \& Jamal R. Exome sequencing identifies SLC26A4, GJB2, SCARB2 and DUOX2 mutations in 2 siblings with Pendred syndrome in Malaysian family. Orphanet Journal of Rare Diseases 201712 40. (https://doi. org/10.1186/s13023-017-0575-7)

29 Fu C, Luo S, Zhang S, Wang J, Zheng H, Yang Q, Xie B, Hu X, Fan X, Luo J, et al. Next-generation sequencing analysis of DUOX2 in 192 Chinese subclinical congenital hypothyroidism (SCH) and $\mathrm{CH}$ patients. Clinica Chimica Acta 2016458 30-34. (https://doi. org/10.1016/j.cca.2016.04.019)

30 De Deken X \& Miot F. DUOX defects and their roles in congenital hypothyroidism. Methods in Molecular Biology 20191982 667-693. (https://doi.org/10.1007/978-1-4939-9424-3_37)

31 Zamproni I, Grasberger H, Cortinovis F, Vigone MC, Chiumello G, Mora S, Onigata K, Fugazzola L, Refetoff S, Persani L, et al. Biallelic inactivation of the dual oxidase maturation factor 2 (DUOXA2) gene as a novel cause of congenital hypothyroidism. Journal of Clinical Endocrinology and Metabolism 200893 605-610. (https://doi. org/10.1210/jc.2007-2020)

32 Liu S, Liu L, Niu X, Lu D, Xia H \& Yan S. A novel missense mutation (I26M) in DUOXA2 causing congenital goiter hypothyroidism impairs NADPH oxidase activity but not protein expression. Journal of Clinical Endocrinology and Metabolism 2015100 1225-1229. (https://doi.org/10.1210/jc.2014-3964)
33 Kizys MML, Louzada RA, Mitne-Neto M, Jara JR, Furuzawa GK, de Carvalho DP, Dias-da-Silva MR, Nesi-França S, Dupuy C \& Maciel RMB. DUOX2 mutations are associated with congenital hypothyroidism with ectopic thyroid gland. Journal of Clinical Endocrinology and Metabolism 2017102 4060-4071. (https://doi. org/10.1210/jc.2017-00832)

$34 \mathrm{Hu}$ X, Chen R, Fu C, Fan X, Wang J, Qian J, Yi S, Li C, Luo J, Su J, et al. Thyroglobulin gene mutations in Chinese patients with congenital hypothyroidism. Molecular and Cellular Endocrinology 2016 423 60-66. (https://doi.org/10.1016/j.mce.2016.01.007)

35 Lee CC, Harun F, Jalaludin MY, Heh CH, Othman R \& Junit SM. Prevalence of c.2268dup and detection of two novel alterations, c.670_672del and c.1186C >T, in the TPO gene in a cohort of Malaysian-Chinese with thyroid dyshormonogenesis. BMJ Open 2015 5 e006121. (https://doi.org/10.1136/bmjopen-2014-006121)

36 Cangül H, Doğan M, Sağlam Y, Kendall M, Boelaert K, Barrett TG \& Maher ER. One base deletion (c.2422delT) in the TPO gene causes severe congenital hypothyroidism. Journal of Clinical Research in Pediatric Endocrinology 20146 169-173. (https://doi.org/10.4274/ Jcrpe.1404)

37 Narumi S, Fox LA, Fukudome K, Sakaguchi Z, Sugisawa C, Abe K, Kameyama K \& Hasegawa T. Mild thyroid peroxidase deficiency caused by TPO mutations with residual activity: correlation between clinical phenotypes and enzymatic activity. Endocrine Journal 201764 1087-1097. (https://doi.org/10.1507/endocrj.EJ17-0194)

38 Sriphrapradang C, Thewjitcharoen Y, Chanprasertyothin S, Nakasatien S, Himathongkam T \& Trachoo O. A novel mutation in thyroid peroxidase gene causing congenital goitrous hypothyroidism in a German-Thai patient. Journal of Clinical Research in Pediatric Endocrinology 20168 241-245. (https://doi.org/10.4274/jcrpe.2503)

39 Szinnai G. Genetics of normal and abnormal thyroid development in humans. Best Practice and Research Clinical Endocrinology and Metabolism 201428 133-150. (https://doi.org/10.1016/j. beem.2013.08.005)

40 Fang Y, Sun F, Zhang RJ, Zhang CR, Yan CY, Zhou Z, Zhang QY, Li L, Ying YX, Zhao SX, et al. Mutation screening of the TSHR gene in 220 Chinese patients with congenital hypothyroidism. Clinica Chimica Acta 2019497 147-152. (https://doi.org/10.1016/j. cca.2019.07.031)

41 Sugisawa C, Abe K, Sunaga Y, Taniyama M, Hasegawa T \& Narumi S. Identification of compound heterozygous TSHR mutations (R109Q and $\mathrm{R} 450 \mathrm{H}$ ) in a patient with nonclassic TSH resistance and functional characterization of the mutant receptors. Clinical Pediatric Endocrinology 201827 123-130. (https://doi.org/10.1297/ cpe.27.123)

42 Ramos HE, Carré A, Chevrier L, Szinnai G, Tron E, Cerqueira TLO, Léger J, Cabrol S, Puel O, Queinnec C, et al. Extreme phenotypic variability of thyroid dysgenesis in six new cases of congenital hypothyroidism due to PAX8 gene loss-of-function mutations. European Journal of Endocrinology 2014171 499-507. (https://doi. org/10.1530/EJE-13-1006)

43 Jo W, Ishizu K, Fujieda K \& Tajima T. Congenital hypothyroidism caused by a PAX8 gene mutation manifested as sodium/iodide symporter gene defect. Journal of Thyroid Research 20102010 1-3. (https://doi.org/10.4061/2010/619013)

Received in final form 26 October 2020

Accepted 29 October 2020

Accepted Manuscript published online 29 October 2020 https://ec.bioscientifica.com https://doi.org/10.1530/EC-20-0411 (c) 2020 The authors Published by Bioscientifica Ltd

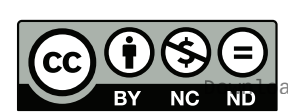

This work is licensed under a Creative Commons Attribution-NonCommercial-NoDerivatives 4.0 International License.ifica com at $04 / 26 / 2023 \quad 02: 56: 12 \mathrm{AM}$ 